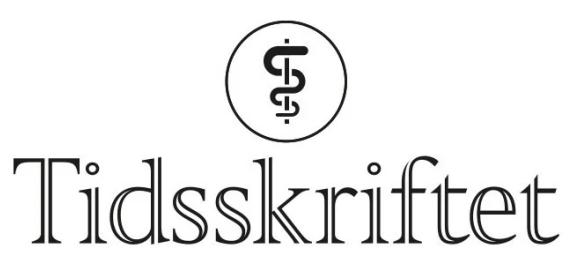

DEN NORSKE LEGEFORENING

\title{
Covid-19: Tanker fra en bekymret mor
}

PERSONLIGE OPPLEVELSER

STINE SANDVEN-THRANE

swthessa@gmail.com

Stine Sandven-Thrane er lege i spesialisering i allmennmedisin ved Jessheim helsestasjon, Ullensaker kommune og nettredaktør for Norsk forening for idrettsmedisin og fysisk aktivitet.

\section{Vi står i en pandemi, med et virus vi foreløpig vet relativt lite om. Jeg er mor til et barn med kreft, og jeg er bekymret.}

Jeg er lege og mor til fem små gutter. Vi er definitivt i den rette alderen for å skulle tåle koronaviruset bra, som tross alt også gjelder de fleste andre. Rundt meg ser det heller ikke ut til at det er viruset folk bekymrer seg mest for. Dette gjelder ikke meg. Tomme butikkhyller er definitivt langt nede på listen over bekymringer nå. Det som gjorde at jeg hver dag uken før barnehager og skoler stengte, vurderte om jeg kunne sende barna mine av gårde, var det faktum at den ene gutten vår har en mye høyere risiko enn andre. Gutten vår er ikke som alle andre barn. Han behandles for akutt lymfatisk leukemi, en kreftform som rammer immunforsvaret - immunforsvaret som skal beskytte oss mot virus og bakterier som trenger inn i kroppen. Den lille kroppen til gutten min har blitt pumpet full av medisiner der målet er å knekke immunforsvaret for å drepe kreftcellene som sitter der.

Han har tre måneder igjen av et behandlingsløp på 2,5 år. Og her står vi i en situasjon med et virus man frykter kan ramme nærmere $30 \%$ av befolkningen og som vil ta mange liv, først og fremst i risikogruppene. Kina har ikke rapportert om dødsfall blant barn under ti år, men dette beroliger ikke meg. Jeg har en sønn der immunforsvaret ikke virker som det skal, en gutt med en kropp som er sliten etter snart 2,5 år med behandling. Så jeg er bekymret, ekstremt bekymret.

Den siste uken og især de siste dagene, har vært preget av et stort tankekaos. Jeg har ikke visst hvordan jeg skal forholde meg til situasjonen landet vårt og verden står i. Skal jeg isolere barna mine og oss hjemme eller skal jeg følge direktivene fra Folkehelseinstituttet og Helsedirektoratet? I det ene øyeblikket ser jeg på sønnen min og hans søsken og tenker at han ser jo helt lik ut som de andre, dette går bra, vi kan leve som de friskeste i samfunnet. Han er sterk og han vil tåle koronasmitte. I det neste øyeblikket ser jeg for meg scenarioet med han liggende på intensivavdelingen med slanger og ledninger over hele kroppen, før tankene farer videre til VG med overskriften «Kreftsykt barn død av covid-19». 
«I det neste øyeblikket ser jeg for meg scenarioet med han liggende på

intensivavdelingen med slanger og ledninger over hele kroppen»

Det er neppe bare hos oss «viruset», som barna mine kaller det, blir diskutert rundt middagsbordet. Hygienetiltak i barnehagen og på skolen, og så stenging av både skoler og barnehager, gjør jo at barna blir veldig bevisste på situasjonen vi står i. De eldste barna spør om vaksine mot korona, og vi voksne må forklare hvordan en vaksine virker. De sier i sin vanlige entusiasme at vi kan lage vaksine av zalo og vann, og presiserer at det må gis i blodårene. Sønnen min med leukemi sier med et smil om munnen at han ikke er redd for viruset, fordi barn ikke blir syke. Jeg smiler tilbake, men sier ingenting, jeg vil jo ikke skremme. Det jeg ønsker å si, er at vår familie må være ekstra forsiktige. Ekstra forsiktige fordi akkurat han er utsatt for å bli alvorlig syk. At jeg ikke vet om han vil tåle det. Jeg har lyst til å fortelle hvor sint jeg er på alle de som ikke ser alvoret i situasjonen, de som er så friske at de ikke er bekymret, som tross de nye oppfordringene om å holde seg sammen med sin nærmeste familie, sender ungene på fotballbanen sammen med mange andre eller reiser på handletur til Sverige. De som tenker at de har fått en velfortjent ferie. De som ikke forstår at de kan smitte en som jobber i helsevesenet, som igjen kan føre til at helsevesenet kneler.

Midt oppi det hele er jeg også lege. En ressurs samfunnet trenger mer enn noen gang. Det å gå på jobb nå er vanskelig. Jeg har mest lyst til å holde meg hjemme for å skåne barnet mitt for smitte. Likevel føler jeg at jeg ikke har noe valg. Jeg må bidra for samfunnet vårt, bidra for alle de som er mer utsatt enn meg selv i denne situasjonen. Jeg håper virkelig alle andre gjør det samme, tenker på andre enn seg selv og sine. Da kan jeg og andre kanskje unngå å måtte isolere oss i mange måneder. Å tenke utover seg og sine er også oppskriften på suksess.

Publisert: 18. mars 2020. Tidsskr Nor Legeforen. DOI: 10.4045/tidsskr.20.0220

(C) Tidsskrift for Den norske legeforening 2023. Lastet ned fra tidsskriftet.no 26. april 2023. 